$\begin{aligned} & \text { Alain Ricard } \text { Towards silence: Thomas Mofolo, } \\ & \text { Alain Ricard (1945-2016) was an } \text { small literatures and poor } \\ & \text { Emeritus Research Professor with the } \text { smales } \\ & \text { University of Bordeaux, France. } \text { translation } \\ & \text { This article was one of the last he } \\ & \text { revised for publication. }\end{aligned}$

\title{
Towards silence: Thomas Mofolo, small literatures and poor translation
}

Despite having written three novels in the first decade of the $20^{\text {th }}$ century, Thomas Mofolo has been largely ignored by historians of literature. The story of the translations of his novels, from 1930 onwards is that of misconceptions and serious misunderstandings. The originality and the complexity of the works discouraged closer readings and they were reduced to simplistic models. This article shows that Traveller to the East and Chaka are not as disparate as they were seen to be at the time. Possible similarities between Thomas Mofolo and Sol Plaatie are also explored. Truth and reconciliation are about reading Mofolo again, and celebrating his example as the first African novelist. Translation is a major step towards reconciliation. Keywords: African literature in translation, missionary publishers, Shaka, Thomas Mofolo,

In his 2008 Nobel lecture, J. M. G. Le Clézio salutes all the writers with whom he lived, and at times against whom he argued, especially African writers: Wole Soyinka, Chinua Achebe, Ahmadou Kourouma, Mongo Beti, Alan Paton, with a concluding reference to Chaka by Thomas Mofolo. The other writers are well known, but Mofolo has always been largely ignored, or even misrepresented, by historians of literature. My first contact with the (excellent) French translation of Plaatje's Mhudi (1930) was a letter in which I was protesting against his inclusion of Mofolo in an anthology of Anglophone writers: as if the Sesotho text had no relevance; as if there was not a specific history of Sesotho textuality.

It is my argument that for an innovative, original, but geographically marginal writer, such as Mofolo, superficial readings place a veil of ignorance on his books and relegate them to an obscure corner of Weltliteratur. My own reading has been influenced by the history of the Paris Evangelical Missionary Society (PEMS) and by the works of Tim Couzens. Drawing on the principle of coherence and seeing a continuity between Mofolo's literary project and his politics, I postulate a unity to his works and I am curious about his entire oeuvre and of course the position of Chaka in it. I am also curious about the various interpretations, produced by a series of translations, from 1930 up to 2007 which provide a frame of interpretation.

The story of Mofolo's translations, from 1931 onwards, is worth going into in some detail. It is a story of goodwill, but also of misconceptions and serious misunderstandings. It is also an eerie tale of dismissing the author. I was surprised to read from his obituary by Victor Ellenberger that Mofolo only died in 1948, but he 
seems to have been completely dissociated from his own works long before that, and detached from their publication in other languages.

\section{Reciprocity and translation}

I want to stress the originality of Mofolo's oeuvre within its context: the Morija station of the PEMS. Missionary work was based on reciprocal translations: the Bible was translated into Sesotho; Sesotho praise poems were translated into French. That was a very original practice which presupposed a positive attitude towards African oral poetry, most uncommon in the mid-nineteenth century. In the same vein, a positive attitude towards recording oral textuality was leading D. F. Ellenberger to draw up historical charts and derive from those charts data on Sotho migrations.

These textual practices by PEMS implied a radical break with the neglect of orality and the contempt for non-written material which characterised the attitudes of many who had preceded them. A legitimate intellectual effort was at work, and this had an impact on Basotho students such as Mofolo. In Chaka, we are given the complete text of a praise song in Zulu: where did Mofolo find that text? Did he transcribe it himself during the course of his travels in Natal? Collections of praises were gathered as part of missionary work. In his book, In the Time of Cannibals, David Coplan quotes Casalis's remarkable piece on the Sotho praise poet, which is still a relevant description of a field performance:

The hero of the piece is nearly always the author. Upon returning from combat he purifies himself in a nearby river, then he goes to put down, religiously, in the depth of his dwelling, his lance and his shield. His friends surround him and demand of him the recitation of his exploits. He recounts them with emphasis; the heat of sentiment leading him on his expression becomes poetic. The memory of the young takes hold of the most striking parts; they are repeated to the delighted author, who ponders over them, and connects them in his mind during leisure hours; at the end of two or three months these children know the praises perfectly, which are thereafter declaimed at the solemn celebrations of the tribe. (qtd. in Coplan 48)

What Casalis has grasped is the essential feature of poetry: the performance of the poem is the poem ("l'exécution du poème est le poème", Valéry 306 ).

Twenty years later, another missionary, Rev. Dohne, did not believe there was poetry among the Zulus, a perspective that is sadly more typical than that of Casalis:

Some have expected to find much poetry among the Zulu Kaffirs, but there is none. In fact poetical language is extremely rare and we meet only with a few pieces of prose. The Zulu nation is more fond of Ukuhlabela i.e. singing and engage more in ukuvula amagama ezinkosi i.e. singing the praises of the chiefs, than any other Kaffir tribe. But their capabilities in this respect are very limited. The highest song of praise for their king is composed of a few hyperbolical expressions (qtd. in Ricard, Les Sable de Babel 238). 
And as A.C. Jordan (15-6) points out, Rev. Dohne knew the language extremely well: His flat denial of the existence of poetry amongst the Zulu speaking people can therefore be attributed not to a lack of understanding of the language, but to his conception of poetry. This conception is implied, rather than stated. Apparently, on looking for trochees, dactylic hexameters, iambic pentameters, rhyme schemes, and not finding them, Dohne should have forgiven the Zulu bards if at least they had composed some poems dealing directly with the stars, the moon, and the Milky Way.

In other parts of Africa, for translators and scholars, to be poetic the language is forced to fit within the schemes of the qasida (an Arabic poetic genre) or of the sonnet: the ideology of the written model permeates all conceptions of poetry, and prevents the understanding of its essential performative, vocal nature within a speech community.

We can maintain that praise poetry was certainly not a common missionary interest as long as we do not forget to make an exception of some members of the PEMS group. Ideas about poetry, the role of poetry, of songs, do influence collection and editing of texts. And what is the point of collecting, if no transcription or no translation is produced within a reasonable time? The first study to be made should be into the history of the practices of collecting, of writing orality, in other words: writing culture. These collections constitute the first corpus of African literature at the beginning of the last century. Very often they include many folktales and narratives and few poems, and were followed by the development of a literature written directly in African languages which was started in full awareness of the first corpus of oral texts. But what was the use of this awareness? Mofolo had a use for it! His novels are a brilliant success built on the knowledge and creativity of his teachers and mentors. He did not shy away from some of the conclusions, such as an enculturation of Christianity: languages, rites, and so on.

\section{Translations}

Reciprocity was not the order of the day in colonial and apartheid years. Very little was translated from African language texts, and almost nothing from one African language to the other: the apartheid government "ruled out the use of translations in African language classrooms in pursuit of ethnic purity" (Hofmeyr 135).

The first English translation of Chaka, published by Dutton in 1931, was sponsored by the then recently founded (1926) International African Institute (IAI); the novel was promoted as the first of its kind (in language and literature) and labelled "An Historical Romance". A few years later, a translation of Moeti oa Bochabela was done by Ashton under the aegis of the Society for the Promotion of Christian Literature (SPCL) in 1934 and was published with no introduction. These two texts are institutional products: the publishers have their own agenda. Quite clearly, the agendas of the IAI and of the SPCL were not fundamentally to promote fiction writing 
among the Basotho. The translator of Chaka rightly understands the importance of the work, and the quality of the prose: a novel, not "historically accurate in all its details" (OUP jacket) but nonetheless in the words of the preface's writer, "a serious contribution to history" (Newbolt xi). Newbolt (xii) points out the Christian point of view of the author, "a soul by nature Christian", which sees in every crisis "the clash of good and evil, of gentleness and militarism, of chivalry and brutality". The author mentions another book, rather perfunctorily, and so does the reviewer in Africa (Smith). Both insist on the Christian dimension and make Moeti oa Bochabela look like an adaptation of Bunyan.

Things changed when Victor Ellenberger took upon himself the task of translating Mofolo and his colleagues (Ricard, "In a Free State"). The first book to be translated into English and then French, Chaka, was actually Mofolo's third book. Its success has caused many misrepresentations: it was the masterpiece that prevented reading the other books, with the focus set on the epic.

Victor Ellenberger proposed his translation of Chaka to Gallimard, the most famous literary French publisher; he did not look for a church publisher, but went for the best general fiction publisher-Proust's publisher-and this is a move of great significance. Ellenberger's agenda was to read Mofolo as a writer, not as a first-class informant, an epic poet, or a missionary wunderkind. The literary head of Gallimard, Jean Paulhan, was a well-respected figure of the Parisian literary establishment, and a major writer himself. But he was also a kind of a rarity: he had been exposed to "Oriental languages", while in Madagascar, learned Malagasy, and published translations of the poems categorised by their distinctive form, the hain tenys. This curiosity had to do with his Protestant background and his acquaintance with the Paris Evangelical Missionary Society. He was certainly aware of the difficulties of translating an "oriental language" (he taught briefly at the school bearing that name in Paris) and of the perils of reducing the work to well-known, but rather inadequate, categories. For instance the mere fact of writing about Chaka should not make us jump to the conclusion that the text will be an epic or that the style should be biblical, the author being a student of a mission. These are precisely the reductive and rather simplistic frames of interpretation which were applied to Chaka. When later the book had made its way to a twentieth century reference library it was at times almost forgotten that it had been written in a Bantu language and even promoted as African literature in English.

Victor Ellenberger translated Chaka around 1930, as far as we can judge from the manuscripts. At the same time, in 1935, in so far as we can reconstruct it, R. Leenhardt, a colleague, translated Pitseng, Mofolo's second novel. It was a slightly different project, an ill-fated attempt to find a new audience for the book by targeting a young audience in church circles. The book was never published. Ellenberger, a few years later, attempted to revise the translation extensively, adding footnotes and 
putting it in line with his previous translations. A careful examination by Limakatso Chaka shows that the translation based on Leenhardt needed a lot of revisions and corrections, and that the work was not completed by Ellenberger. His son attempted, without success, to finish the task. A few years later, Ellenberger also translated Moeti, but could not find a publisher.

Reading these two translations into French (of Moeti and Chaka) is an original experience which provides a different context, in showing the obvious relations between the two texts. Why was this closeness not highlighted? The texts had been assigned to different genres: Moeti was labelled a Christian apologia and Chaka a historical novel, and the apparent exaltation of the syncretic power of Christianity in the former novel seemed far removed from the African Nationalism of the latter. To us, today, these two positions do not seem antagonistic, or rather we can figure out ways of reconciling them, but in the South Africa which protected apartheid, or even more in colonial Africa, these two historical views seemed incompatible. Fekisi, the aspiring Christian was not a power hungry self-made king like Chaka.

Ethnographic interest, not entirely disinterested in those high colonial times, nor devoid of heavy presuppositions, was lingering in the background: the IAI version of Chaka starts bizarrely with a note on pronunciation of African names, by Alice Werner: why would a novel include such information? Is it because it will be read aloud, or because it was somehow heard? The French translation includes 102 footnotes, precise and short. The translation bears a subtitle, une épopée bantoue, a Bantu Epic. In the new printing of the book (1981) the original 1939 preface by Zakes Mangoela, which placed Mofolo within the context of the Morija mission and of its circle of writers, has been discarded, thus reinforcing the myth of the lone epic poet and, most unfortunately, but quite logically, the actual preface by 2008 Nobel Prize recipient, Le Clézio, focuses on the collective expression of a people, not on the creative work of a fellow writer.

But a breakthrough had been accomplished: in the 1991 Gallimard Catalogue, only two writers from sub-Saharan Africa featured in the World Literary Series $(D u$ Monde Entier): Thomas Mofolo, translated from Sesotho (1940); and Amos Tutuola, "translated" from Nigerian English (1954) by Raymond Queneau, a close friend and associate of Jean Paulhan. Many decades later these two African writers are still with us, as masters of language and major literary figures of the twentieth century.

I will explain later the calamitous reception of the first published French translation. Let us note that the second French translation (of the first book, Moeti) had to wait until 2003 to be published, and then thanks to Paul Ellenberger, son of Victor, who had himself been a minister in Lesotho, and spent a great deal of time and energy to provide a readable and annotated version of the book. The English translation (1934, reissued in 2007) was not widely read, and was promoted from the start, in an advance summary, as "something like a mixture" (sic) of Bunyan and Olive 
Schreiner (Newbolt ix): a boy who walks away from an African kraal to become Christian calls for these absurd prefabricated labels that stuck for a long time. The Bunyan model was repeatedly applied to that book, despite its obvious differences and brilliant style. The only other book, Pitseng (1910), was put aside, considered a love story, neither read nor translated, until recently. In 2013 an English translation by Daniel Kunene was published and Chaka has closely examined the book using the French attempts at translation.

As we know, Paul Ellenberger, son of Victor, was the grandson of David-Frédéric who had written in Sesotho a History of the Basuto in 1913 (Ricard, "In a Free State"). The grandfather had switched from French and later English to Sesotho, and his son and grandson were going the other way, translating from Sesotho to French. They took their place in a long line of scholars and missionaries whose commitment to Morija and the Lesotho Church has been unfailing despite many setbacks and even catastrophes, such as Jacottet's poisoning in 1920 (see Couzens, Murder).

The Ellenbergers had their own agenda in working on Mofolo: to make of him a writer of renown and influence. They succeeded, since Chaka by Senghor (1954) and by many other writers (see Vassilatos) are offshoots of the book published in 1940. Senghor's poem transformed the Chaka story, adding the dimension of tragedy and of the loneliness of the man of power, which became a rather standard reading of the Chaka "story" (but not of the novel). It was as if suddenly the book had been stripped of its complexity, of its own context, and reduced to a tragic and rather simplistic vision of history: African nationalists versus the rest of the world. A complex novelistic character became an epic icon, carved in a single piece. It was certainly hard to be "nuanced" in those years of booming apartheid, and I understand some of the pressures of the times, but the success of Mofolo's book was built on many a creative treason. The ostentatious institutional praise was entwined with a strategy of confinement: no translation in other African languages, a late translation in Afrikaans, and translations to other European languages, usually using the English version as a go-between. In this process the poetic and original quality of Mofolo's language was lost, the historical and epic character of Chaka emphasised, and some of the most unpleasant aspects of his kingship forgotten or put aside in favour of a heroic, positive version of the character.

Mofolo was eventually "devoured" by Chaka: not only was he absorbed by his hero, he was also confined or diluted in the historical debate. To achieve publication with Gallimard was a tremendous success in itself, but became a disastrous failure when the book came out. The book was published in late 1939. Three printings were made, no reviews published (Gérard, "Relire Chaka"). Not only was the timing bad, but right after the publication and the invasion of France by the Nazis, Gallimard issued a publicity leaflet which was a deliberate provocation to the Nazis in that Hitler was likened to Chaka: 
A hungry adventurer, greedy, unscrupulous, succeeds through his cleverness and with the help of dark powers in conquering supreme power. Identifying his ambition with his nation's destiny, he reorganises the state with iron discipline, institutes obligatory military service, turns all activities towards war, then, thanks to audacious tactics, subjugates neighbouring peoples, succeeds step by step, pushing millions into unspeakable carnage, while, drunk with blood, massacres even his friends and benefactors. He himself is assassinated by his closest collaborators, leaving his nation exhausted and soon to be enslaved by foreigners. To avoid all confusion, let us specify that these events occurred more than a century ago in Southern Africa and that this bloodthirsty tyrant is named Chaka, king of the Zulu. (qtd. in Ricard, "In a Free State" 218)

As could be expected, in occupied Paris, the book was taken off the shelves and the translation disappeared after that. It had, however, a number of readers, a career in French, was read by Senghor, and reissued several times with an original preface by J. M. G. Le Clézio. The murder of Noliwa, purportedly an invention of Mofolo, is actually the basis of Senghor's work and provides the tragic structure of his poem. This would indicate that Senghor read Mofolo, and read him well (see Gérard, "Relire Chaka" and Vassilatos).

\section{From Moeti oa Bochabela to Chaka}

If I follow Paul Ellenberger's personal comments to me on the English translation of Moeti oa Bochabela (1934), some severe mistakes were made-and retained, to my dismay, in the new edition by Penguin published in 2007, obfuscating the Sotho religious dimension and ironing out conflicts between Christianity and indigenous religion. Ellenberger produced an elegant and, as far as I could judge, precise translation of Moeti oa Bochabela. I worked with him in his home and he explained a few key points relating to the parallels between the novels and more generally to the universe of Mofolo. Moeti oa Bochabela opens up Sesotho literature but many patches of shadow remain.

It is the story of a Mosotho from the days before the missions who, disgusted by the turpitudes of paganism and intrigued by the mysteries of nature, leaves his village and makes his way towards the east in order to find an answer to the questions torturing his soul. Through the greatest privations and through numberless dangers, he reaches the sea, is captured by white smugglers, is taken by them to their country, learns about the Revelation and dies of happiness on the day when, for the first time, he is permitted to approach the Lord's table (Livre d'Or 508). ${ }^{1}$

Moeti oa Bochabela (1907) is a prophetic and syncretic text, and not a mere translation of a Calvinist demonstration by a traveling Pilgrim. Fekisi, the hero, lives in the "old times, when this land of Africa was still clothed in great darkness, dreadful dark- 
ness, in which all the works of darkness were done. It is the days when there was no strong chieftainship, the tribes still ate each other" (Moeti 8). Fekisi searches for God and, rejecting the customs of his Sotho ancestors, finds the light of the Orient on Mount Sion (123). The "Son of Man" invites him to follow him and Fekisi enters the holy city where he reigns with God because he had no fear and left his country for the love of God (124). The construction of narrative is well conducted and Mofolo was congratulated for his achievement: "With what charm, what picturesqueness, what liveliness, this story has been told! Its style is pure, its language excellent; a masterpiece in our opinion!" (Livre d'Or 508). ${ }^{2}$

The novelist has an acute consciousness of the creation of a literary language. He tells something that has never been told: to leave his culture, to start towards a new horizon, to cross the sea, to encounter new peoples. The narrative starts from within the culture; it is not an abstract world: it is a world permeated with the sounds and the words of Sotho villages. The novel reconfigures the world experience of a Sotho shepherd in a totally new way. It is the story of a conversion, of a pilgrimage, of a solitary adventure. But it is a society viewed by an individual who suddenly presents in a new way what has always been there.

There is an important moment in the middle of the novel, in chapter five, when Fekisi decides to leave his village; this is truly the turning point in the narrative. Instead of going away, of giving up on the 'pagans' as we tend to believe he did from superficial accounts of the novels compounded by bad translations, Fekisi makes a pilgrimage to his kraal. He talks to his cows. Chaka would do the same some years later in another novel. As we know, cows have a role in the religion of the Basotho. For instance, King Moshoeshoe I could not circumcise his son if he did not spread the offal of a cow on the grave of his grandfather. The cows are not merely a meat reserve: they embody memory and faith. The translation by Ellenberger makes this abundantly clear in its precise translations of Sotho terms.

So what does our "Proto-Christian" say to these "divine" bovines? He sings their praises. What emerges from this chapter, a central one in the book, is not exactly the picture of a devout Christian rejecting all of his native culture. Fekisi dreams, praises and goes. It is the individual quest of a character who is totally immersed in his own culture and who does not condemn the initiate. On the contrary, the animals seem to encourage him to go; they seem to be his accomplices. He has a way of communicating with them which is the product of a long relationship: he knows them, they know him, his smell, his noises, his sounds. The place of nature in the novel is truly original.

Performing the praise poems places Fekisi squarely within his culture, and it is surely not a detail if he does so at the time of his departure. What is new in the novel is precisely the syncretism: verbal syncretism of praise eulogies spreads throughout the narrative as Kunene shows convincingly; as does religious syncretism, as I am 
trying to show. Obfuscation of the Sotho religious context is a recurring difference between the French and the English translations. Where in English we have the "girls", Ellenberger in French translates the Sotho term, bale, as the "initiates": quite a different understanding. The cow is "Dieu au nez humide" (God with a wet nose) ("Ea molimo o nko e metsi", Moeti 37).

But in a world which was heading towards separate development this practical apologia for syncretism was doomed to fail and to remain misunderstood. Albert Gérard gives an account of Beuchat's reading of the novel: "Moeti oa Bochabela is interesting in that it shows the merging of Sotho beliefs and Christian thoughts" (Gérard, Four African Literatures 111), but without the textual examples and in a context of separate development, the point is easily missed. In any case its subversive content is eradicated. The figure of the writer is partly the figure of a prophet: he delivers in a totally original way, in a new medium, an original message. Mofolo was also, in his own way, something of a prophet.

Daniel Kunene carried out a brilliant and unique philological study of Mofolo in 1989. He was equipped to do that after studying Basotho oral poetry (Kunene Heroic Poetry), and understanding the poetic resources of the language. His book demonstrates the qualities of Mofolo's style: a capacity to use formulas from oral texts, to tag them to nouns, to describe, with a curiosity for nature and landscape which translates into wide panoramic scenes without equivalent in oral poetry.

Mofolo is not an imbongi, he does not mobilise the same kind of knowledge and, may we ask how a Mosotho could know the praises of a Zulu king? After all the praises are like religious hymns: they are culture specific, they function specifically in one language. The same processes are applied in all languages, but I suggest that it would be strange, and is to me "unheard of", to know oral praises in different languages-except for scholars of oral poetry. Mofolo has heard them (during his trips?), read them, knows how to recognise them, and he uses formulaic phrases which are found in Fuze's (1925) book on the Zulu. It is a literary borrowing, not a tribute to memory. Mofolo keeps his distance from his character, Chaka

Two hermeneutic angles deserve to be considered in reading Mofolo: land and gender. Love of the land is a central feature of Mofolo's writing: he knows how to describe the country, its beauties, its fauna, its flora. Animals seem to mediate between the supra-natural world and nature, but we are not dealing with allegories, rather with descriptions of landscapes. Animals are living in their environment, not in a mythological world.

The lion hunt is a proof of manhood: in Moeti, Fekisi, the devout shepherd, kills two lions, while Chaka the brave future king, only kills one. As we know, the cows, "gods with the wet noses" are the main mediation between ancestors and men. Fekisi in chapter five speaks and sings to his cows, and so does Chaka. The kraal is not only a corral: it is also a religious space. 
Another scene is repeated with a small difference, quite significant in my view. While crossing a river, Fekisi meets an enormous serpent, coming out of the water, a frightening figure, who looks at him and sticks out two tongues; Fekisi stands his ground, and the snake goes away. A snake, called by the author the "Lord of Deep Waters", appears to Chaka, pulls out his two tongues, embraces the young hero, and makes a collar with his tongues around Chaka's neck. In the book this encounter is a kind of recognition, the signing of a pact with the powers of violence and domination.

Emphasis on landscape certainly distinguishes the novels from oral literature, which does not indulge in descriptions. Victor Ellenberger provides many footnotes on this aspect of the book. In Moeti oa Bochabela the hero goes across unknown lands but is not prevented from crossing into other countries; his geography has a mythical character. In Pitseng the hero is a well-travelled lad who has been to South Africa, has ridden on trains, and finally settles in a beautiful valley. The scenery with falling snow is spectacular. Pitseng is a pastoral novel: love and happiness are to be found in a beautiful valley, a dream land where nature is offered freely.

Everything changes in Chaka which starts its panoramic view of the country and of Southern Africa, as if suddenly this entire world was considered at the time of its dislocation: the book was ready in 1910 when the Union of South Africa was proclaimed, the autonomy of Lesotho under threat and the Land Act promulgated in 1913. Suddenly the land is no longer free for wanderers; hospitality is no longer what it was in Pitseng when the traveller could knock at any door. Labels have been stuck to people; but is the answer to that challenge to be found in Chaka's action? Is the future the regimenting of the world, the creation of cities organised as military camps in the Roman style? Chaka's camp-capital impresses Mofolo, the young traveller, but he does not advocate following his model.

The control of allocation of women is a central political device for Chaka. But of course the point of view of the girls is rarely mentioned and we can safely assume that this bondage is not really appreciated by its victims. In Moeti oa Bochabela, Fekisi is greatly appreciated by the village girls because of his honesty, generosity and courage; they regret his departure, they will miss him. The second novel, Pitseng is a love story in a pastoral setting between a school teacher and a village beauty who is also a great singer: truly a utopia. In Chaka the hero is admired by the village girls for his courage and beauty, but his interest in them is soon transferred to other pursuits. After reaching the supreme power, changing the name of his people, Mofolo lets us understand his critical point of view: he comments dryly on Chaka's tastes, "not attracted by women".

But Chaka does not care: actually he cannot really relate to any woman. He makes use of dozens of girls from his harem, kills his mistress, and his own mother. Losing the harem may have been a different issue, a net capital loss. Mofolo, who has mentioned the homoerotic element in Chaka's idolatry of himself, comments obliquely on the women's point of view in chapter 20 . This is indeed a very ironic 
scene: the Great King Chaka welcomes his tributaries, and enjoys listening to praises from Moshoeshoe, the Sotho king, delivered by his ambassadors; but in the next page the "Great King" suffers the desertion of his main general, Mzilikazi, his best soldiers, and most of the harem. Suddenly the silent subjects of the despot have their own agency: they flee, and we can safely assume that they are very happy to play such a good trick on Chaka, the masculine icon.

This episode is situated, in the book, between the murder of Noliwa and the murder of Chaka's mother, as if to restore some sense of historical initiative to women, despite the bondage and the cruelty of their master. Mzilikazi is leading the flight: the Ndebele king is not a character of Chaka, but a central character in Mhudi, Plaatje's novel. Mhudi, the main female character, can be interpreted as a female opposite of Chaka: she also kills a lion with her boyfriend, she always defends women, she is a promoter of peace and discussions. In 1920 the Chaka manuscript still lies unpublished; Plaatje completes his own manuscript of Mhudi, and has to wait ten years to publish it, in Lovedale.

\section{From Chaka to Mhudi: the pressures of colonisation}

The work of Daniel Kunene is a labour of respect and of love. I have a copy of the brochure on Mofolo he published at UCLA in 1967, when I was briefly his student. Mofolo was not a praise singer or a bard; he was a man of the book, of paper, of the printing shop. As Kunene was saying (Thomas Mofolo 4), with initiatives such as the Heinemann African Writers' series critics finally realised in the sixties that Africans wrote books, but seemed to imply that they had only just begun.

Mofolo disappeared from the literary scene while still alive, in his twenties. He was living in the same world as ours, except that he was black in a country surrounded by a country where racism was soon to be fully institutionalised. Being from Lesotho he would avoid some of its consequences, and even, acting as a middle man or a recruiting agent, profit from it.

His colleague and almost exact contemporary, Sol Plaatje, was living not far from him. I travelled to Mafikeng-Mmabatho, where Plaatje had been an interpreter, visited Kimberley, went to Angel Street, and saw his house appropriately transformed into an elementary school. I read his biography by Brian Willan, and a selection of his prose. I tried to imagine the complexity of their relations which are recorded nowhere, maybe because there is no recording, no archive. We need to reconfigure the archive, and make some hypotheses. If we align two sets of dates, there seems to be a substantial probability of encounters and certainly of acquaintance with each other's work. But their differences are also obvious, and illuminate their work, perhaps helping us to understand Mofolo's silence, which remains an enigma to many.

Plaatje became the first Secretary of the South African Native National Congress, which was later to become the ANC, in 1912. Basutoland was not in the Union and 
Mofolo had just left Morija. After an adultery case, he chose to exile himself to what is now northern Zambia, and later went to Johannesburg to join Ernest Mabille, expelled also from the PEMS, as a recruiting agent.

It was through this connection that he was dispatched to Leribe in 1912 as a subagent for the Eckstein/Rand Mines group. Mofolo went on to accumulate enough wealth to establish a mill in Teyateyaneng in 1921, as well as a mail/taxi service between there and Ficksburg. When his position improved still further, he extended his little empire in the 1920s, recruiting for several diamond mines, farms, and a number of Natal sugar estates. He also opened stores in Bokong and Teyateyaneng. In 1937 he sold his property to buy a farm in Matatiele, but later became bankrupt after a futile struggle to protect himself from the Land Act in South Africa (Maloka 45-6).

The Land Act of 1913 was the foundation stone of apartheid, and one whose consequences still remain today. Sol Plaatje foresaw this and campaigned against the Land Act. His Native Life in South Africa, published in 1916, is a masterpiece of clarity, with the lucidity of the thinker, of the idealist intellectual, trying to build a better society. The book was not translated into French, nor to my knowledge into any other language.

I taught a graduate seminar some years ago comparing the two books, Chaka and Mhudi, and was struck by their capacity to enter into a dialogue: on power, on gender, on violence, on chiefs, on the place of white men.

Both writers for some years shared the unpleasant experience of already having books in print-and significant books (we are still talking about them a century later)—and of not being recognised as legitimate writers, only by missionaries and anthropologists. Thomas Mofolo, being from Lesotho, had in his marginality opportunities, as did Solomon Plaatje, as a Cape subject invested in the "Cape franchise", until he lost all hope in the 1920s.

Chaka was not read in its own proper field of interpretation. But what field would be proper? Other novels in Sesotho? Novels in English by black writers? Why did Plaatje write in English? Was not the example of Mofolo's reception a clue to the opportunities, or lack of it, given to black writers? Because of the poor reception of Mofolo, nobody seemed to be aware that these two had a great deal in common even though they did not share the same script and the same Sotho language. The novel is a way to make sense of history, to propose other paths, to reflect upon what has been happening. Black South African writers, especially novelists, were neither known nor translated (Mhudi, in French only in 1997) and remained marginalised in South Africa during colonial times (until 1994) not because they came from a country that was too exotic, too different, and thus incomprehensible, but because they were representative of the state of affairs in the whole continent. The simple fact of their achievements was a denunciation of apartheid which resounded too loudly in Africa. It was echoing all sorts of discriminations, inequalities and vexations 
of colonial times. That precisely was the reason for their marginality: they were too vocal and too precise in their nuanced criticism of the colonial system. These natives did not stay in their place.

\section{Towards silence}

Arthur Rimbaud (1854-91) is considered one of the most important French poets. At the age of nineteen, after a brief participation in the Paris Commune, he stopped writing and went to Africa to become an explorer, a trader and a gun dealer. An adventurous spirit, a powerful imagination, a beautiful sense of verse and proseand then silence. Silence may come from hyper-lucidity with respect to literature. Rimbaud did not want to posture as a man of letters. I suggest that Mofolo shared the same fatigue, the same sense of having understood too much. I tend to think that his heroes, Chaka and Fekisi, are still with us, and that his books still resonate within us a century later. Mofolo was a writer deprived of a literary milieu: a vox clamans in deserto. Plaatje had travelled, and, from the Cape Province politics, had more resources to understand the situation; he left us texts in which he articulated his clear and increasingly desperate understanding of his predicament, whereas he had been more optimistic at least at the beginning of his career.

At a symposium dedicated to Janheinz Jahn, some years ago I made the comment that Soyinka can be read, and even more appreciated, against a backdrop of mediocre playwrights, pompous poets, boring narrators (see Ricard "Creative Writing"). No such backdrop existed for Mofolo. This is an essential point in the workings of literature as institution, and it is precisely there that we have difficulties in many African-language literatures. There is simply no community of writers to create the kind of milieu, the horizon against which to appreciate the claims of innovation, of relevance, of experiment. Un ouvrage d'imagination absolument original, was the comment of the Morija ministers when Moeti oa Bochabela as first published (qtd. in Ricard "Un Ouvrage" 87).

Dialogic translation, the work started by Arbousset and Casalis, had in my view a tremendous enabling effect; it showed the respect given to African textual productions. The future was not one-sided. Texts are fragments of discourse that last (Barber) and offer some traçabilité. This is precisely what the genealogical charts of D. F. Ellenberger were trying to do. All these processes can be called textuality and happen in a given historical context. In the first third of last century, diamonds were found, land was fertile in the area between Lesotho and Kimberley, along the Orange River, in the Sotho-Tswana area. Consequently black people were pushed out of their lands and deprived of their freedom. Writers, with a prophetic vision such as Mofolo, or a utopian hope such as Plaatje, could only be left aside: they were asking too many vexing questions. Truth and reconciliation are also about reading them again, and celebrating their examples. 
Notes

1. “C'est l'histoire d'un Mossouto des temps antérieurs aux Missions, qui, dégoûté par les turpitudes du paganisme et intrigué par les mystères de la Nature, quitte son village et se dirige vers l'Est, afin d'y trouver la réponse aux questions qui tourmentent son âme. A travers les plus grandes privations et des dangers sans nombre, il arrive à la mer, est recueilli par des trafiquants blancs, conduit par eux dans leur pays, apprend à connaître le Révélation et meurt de bonheur le jour où, pour la première fois, il lui est permis de s'approcher de la Table du Seigneur" (Livre d'Or 508).

2. "Mais avec quel charme, quel pittoresque et quelle vie cette histoire est racontée!" (Livre d'Or 508)

\section{Works Cited}

Barber, Karin. The Anthropology of Texts, Persons and Publics: Oral and Written Culture in Africa and Beyond. Cambridge: C U P, 2007.

Bunyan, John. The Pilgrim's Progress. London, 1678.

Chaka, Limakatso Elizabeth. "Etude stylistique et thématique de Pitseng roman de Thomas Mofolo (1910)." Mémoire DEA. Université de Paris, 2005.

Coplan, David. In the Time of Cannibals. Berkeley/Los Angeles: U of California P, 1994.

Couzens, Tim. The New African: A Study of the Life and Work of H.I.E. Dhlomo. Johannesburg: Ravan Press, 1985. . Murder at the Mission. Johannesburg: Random House, 2005.

Ellenberger, David-Frédéric \& J. C. McGregor. History of the Basuto Ancient and Modern. Morija: Morija Museum and Archives, 1992 [1912].

Fuze, Magema M. The Black People, and Whence they Came: A Zulu View. Pietermaritzburg: U of Natal P and Killie Campbell Library, 1979 [translation of Abantu Abamnyama, 1922].

Gérard, Albert. Four African Literatures. Berkeley / Los Angeles: U of California P, 1971. . "Relire Chaka, Thomas Mofolo, ou les oublis de la mémoire française." Politique africaine 13 (1984): 8-20

Hofmeyr, Isabel. The Portable Bunyan: A Transnational History of The Pilgrim's Progress. Johannesburg: Wits U P, 2004.

Jahn, Janheinz \& Claus Peter Dressler. Bibliography of Creative African Writing. Nendeln, Liechtenstein: Kraus Thomson, 1971.

Jahn, Janheinz. Who's Who in African Literature. Biographies, Works, Commentaries. Tübingen: Horst Erdmann Verlag, 1972.

Jordan, A. C. Towards an African Literature: The Emergence of Literary Form in Xhosa. Berkeley/Los Angeles: $\mathrm{U}$ of California P, 1973.

Kunene, Daniel. The Works of Thomas Mofolo. African Studies Center, UCLA. Occasional Paper 2, 1967. . Heroic Poetry of the Basotho. London: O U P, 1971.

Thomas Mofolo and the Emergence of Written Sesotho Prose. Johannesburg: Ravan, 1989.

Le Clézio, J. M. G. "In the forest of paradoxes." Nobel lecture. 7 Dec. 2008. 1 May 2015. < https://www. nobelprize.org/nobel_prizes/literature/laureates/2008/clezio-lecture_en.html>.

Livre d'Or de la Mission du Lessouto. Souvenir du Jubilé célébré en 1908. Paris: Maison des Missions Evangéliques, 1912.

Mabana, Kahiudi Claver. “La Réécriture francophone du mythe de Chaka." Matatu 30-31: (2005): 61-71.

Maloka, Eddy. Basotho and the Mines: A Social History of Labour Migrancy in Lesotho and South Africa, c.1890-1940. Dakar: CODESRIA, 2004.

Mofolo, Thomas. Chaka. Morija: Sesuto Book Depot, 1925. . Chaka. An Historical Romance. Trans F. H. Dutton. London: O U P/International African Institute, 1931. Chaka : une épopée bantoue. Trans. Victor Ellenberger. Pref. Z. Mangoaela. Paris: Gallimard, 1940. Chaka. Trans. Daniel P. Kunene. London: Heinemann, 1979.

L'homme qui marchait vers le soleil levant. Trans. Victor Ellenberger. Bordeaux: Editions Confluences, 2003.

. Moeti oa Bochabela. Morija: Sesuto Book Depot, 1907.

. The Traveller to the East. Trans. Henry Ashton. London: Society for Promoting Christian Knowledge, 1934.

Newbolt, Henry. "Introduction”. Chaka: An Historical Romance. Thomas Mofolo. Trans. F. H. Dutton. London: O U P / International African Institute, 1931. vii-xv. 
Plaatje, Sol. Mhudi. Johannesburg: Quagga Press, 1975 [1930].

. Mafeking Diary. Ed. John L. Comaroff. Johannesburg: Southern Books Publishers, 1989.

. Native Life in South Africa, London: Longman, 1983 [1916].

. Selected Writings. Ed. Brian Willan. Johannesburg/Athens (OH): Witwatersrand U P/Ohio U P, 1996.

Ricard, Alain \& Chris Swanepoel. “Towards a New Philology." Research in African Literatures 28.1 (1997): 1-2.

Ricard, Alain. "Creative Writing in African Languages: Writers, Scholars, Translators." Beyond the Language Issue: The Production, Mediation and Reception of Creative Writing in African Languages. Eds. A. Oed \& U. R. Jahn. Köln: Rudiger Koppe, 2008. 145-52.

Ebrahim Hussein: Swahili Theatre and Individualism. Dar es Salaam: Mkuki na Nyota, 2000.

. "In a Free State: Translation and the Basotho: From Eugène Casalis to Antjie Krog." Writing and Translating Francophone Discourse. Ed. P. Bandia. Amsterdam/New York: Rodopi, 2014. 205-24. Le sable de Babel. Paris: CNRS Editions, 2011.

. "Un ouvrage d'imagination absolument original: Moeti oa Bochabela de Thomas Mofolo: Premier roman africain". Matatu 30-31: (2005): 87-98.

Rimbaud, Arthur. Oeuvres complètes. Paris: Cluny, 1942.

Smith, Edwin. "A Review of Chaka". Africa 1.4 (1931): 506-8.

Tutuola, Amos. The Palm-Wine Drinkard and his Dead Palm-Wine Tapster in the Deads' Town. London: Faber and Faber, 1952.

Valéry, Paul. Variétés. Paris: Gallimard, 1960.

Vassilatos, Ellas Alexia. The Transculturation of Thomas Mofolo's Chaka: Southern Africa and Francophone Africa in Dialogue. PhD diss. U of the Witwatersrand, 2007.

Visser, Nick \& Tim Couzens, eds. H. I. E. Dhlomo: Collected Works. Johannesburg: Ravan Press, 1985.

Willan, Brian. Sol Plaatje: South African Nationalist. London: Heinemann, 1984. 